\title{
South African Journal of Military Science
}

\section{Editorial}

From a defence and security point of view, the second half of 2021 has been largely dominated by the frantic final withdrawal of the United States (US) and North Atlantic Treaty Organisation (NATO) forces from Afghanistan during August. This withdrawal practically signalled the end of a twenty-year-long deployment that followed in the wake of the September 9/11 attacks. The rapidly changing security situation in Afghanistan, which ultimately boiled down to a humanitarian crisis, was underpinned by the all but complete collapse of the Afghan government, the disintegration of Afghan National Army (ANA), and the occupation of Kabul by Taliban forces on 16 August 2021. I incidentally speculated about the unfolding of these very events in the editorial to the previous issue of Scientia Militaria. Nevertheless, there is no doubt in my mind that military practitioners and academics will closely monitor the situation in Afghanistan as it develops over the coming months. These events will also force the United States and its NATO allies to reconsider the entire Afghanistan adventure, which was one of the main focus areas of their geo-political and defence efforts for the last twenty years. They will also need to ask several searching questions about the counterinsurgency approach adopted in Afghanistan by the coalition forces and which ultimately led to the collapse of the Afghan government and the ANA. The unravelling of the Afghanistan adventure means that issues such as defence policy, doctrine, force structure and design, coalition operations, the propping up of governments, and irregular warfare to name but a few, will be placed under the spotlight by soldiers and scholars alike over the coming years.

The Far East has also been marked by heightened tension over the past few months. Of growing concern is the brazen testing of new ballistic missile systems by the Democratic People's Republic of Korea (DPRK) in the waters off the coast of Japan. These tests occurred in direct violation of the international sanctions imposed against the DPRK, and could derail any hope of sustained and substantive dialogue with the United States, Japan and the Republic of Korea. If further provocations by the DPRK are left unaddressed, the geo-political situation in the region could worsen to the extent where military intervention might become a stark reality. The People's Republic of China (PRC) has also been in the spotlight recently for its continued heavy-handed approach in dealing with dissention in Hong Kong, and its growing military tension with Taiwan during the past few months - this includes several unflinching breaches of Taiwan's air defence zone, and the ever-present threat of a full-scale invasion of the island nation. We can only hope that constructive dialogue and the upholding of the so-called 'Taiwan Agreement' will help to bring the situation under control sooner rather than later. 
In Southern Africa, the primary focus remains on the operational deployment of Southern African Development Community (SADC) and Rwandan forces to the ungoverned territory of Cabo Delgado in northern Mozambique to combat the Ahlu-Sunnah WaJama (al-Shabaab)-linked insurgents. While the counterinsurgency operations by the SADC and Rwandan forces have been largely successful in terms of locating, isolating and neutralising the al-Shabaab insurgents, we now have to start considering issues such as post-conflict reconstruction and development, the re-establishment and maintenance of law and order, the provision of basic services, and - above all - dealing with the key drivers of the insurgency in the first place. If these matters are not addressed adequately by the Mozambique government in the long term, the security situation in Cabo Delgado may never stabilise - which could realistically see the prolonged deployment of SADC forces to northern Mozambique.

Closer to home in South Africa, the country was rocked by large-scale civil unrest, violent protests and rampant looting over the period 9-18 July. These incidents were mainly confined to the provinces of Gauteng and KwaZulu-Natal, and occurred against the backdrop of the imprisonment of former President Jacob Zuma for contempt of court. In order to help the South African Police Service re-establish order and control in the affected areas, the South African National Defence Force (SANDF) deployed nearly 25000 soldiers under the auspices of Operation Prosper. While the deployment of the troops helped to quell the civil unrest in mere days, it laid bare the fact that the SANDF is severely over-stretched and critically underfunded for such an undertaking - especially against the backdrop of the current troop deployments to the Democratic Republic of the Congo and Cabo Delgado. Moreover, the civil unrest also raised questions about the local security vacuum and rapid response capabilities that were lost with the closure of the part-time commando forces of the South African Army between 2004 and 2008. We will closely monitor the ramifications of the civil unrest over the coming months, in particular the nature and scope of the subsequent police and military deployments.

In this issue of Scientia Militaria, Vol. 49, No. 2, 2021, the articles consider both historic and contemporary issues associated with war and conflict, as well as defence and security-related matters. As always, it is trusted that these articles will provide key insights and act as a source of influence for individuals involved in the broader ambit of military planning, operations, management and higher education.

The article by Piet Bester and Sonja Els considers the security-vetting dilemma created by the legalisation of cannabis in South Africa. The authors were particularly interested in exploring whether the legalisation of cannabis could influence vetting decisions on the security competence of employees. The fact that relevant South African security vetting literature pays no scholarly attention to the issue of the legalisation of cannabis, and the way such legalisation will influence the vetting decisions of an applicant's security competence, remains alarming. This state of affairs then leads to what can be referred to as a 'security-vetting dilemma', where a situation may arise where the efforts to ensure the security of the state or the relevant department may lead to a direct infringement of the rights of the individual. Bester and Els therefore analyse existing South African cannabis-related legislation and explore cannabis as substance and its 
effect on the individual, before they investigate its impact on the workplace. The article also reflects on the security-vetting implications of cannabis use and the management thereof in the workplace, after which a summary and recommendations are proposed for vetting institutions.

In his article, Boris Gorelik reassesses the role of the Russian volunteers in the collapse of the international legion during the South African War (1899-1902). By reexamining primary sources, and in particular the first-hand accounts of legionnaires and observers, the author investigates the military career of Lt Col Yevgeny Maximov from the 1870s in order to establish his status in South Africa before and after joining the international legion led by the famous General Georges de Villebois-Mareuil. After De Villebois-Mareuil's death in April 1900, Maximov succeeded him as the commander of the international legion amidst strong opposition and criticism. Gorelik attempts to understand the legionnaires' subsequent opposition to Maximov better by scrutinising the often-quoted book by Sophia Izedinova, a Russian nurse who served with the RussoDutch Ambulance, and by far the most dedicated chronicler of Maximov's career in South Africa.

The article by Lungani Hlongwa reports on an investigation of the role of artificial intelligence and Big Data in the Belt and Road Initiative (BRI) - China's vision of transcontinental and transoceanic economic integration through trade. While China's BRI has attracted considerable and diverse academic interest, the focus remains largely on the land and sea dimensions. Hlongwa draws attention to the digital and maritime dimensions of the BRI, which are respectively known as the Digital Silk Road Initiative (DSRI) and the Maritime Silk Road Initiative (MSRI). He specifically considers how artificial intelligence and Big Data, as promoted under the DSRI, intersects with the MSRI to produce what he refers to as Seapower 2.0. Based on patent analysis, the article shows that artificial intelligence and Big Data will play a crucial role in future supply chains, and hence the MSRI. While the article primarily focuses on the commercial side of Seapower 2.0, the author also discusses the role that artificial intelligence and Big Data could serve for military objectives.

In their article, Nomboniso Moss, Ivan Henrico and Hennie Smit discuss food wastage management at the South African Military Academy officer's mess. The motivation for the article stems from the fact that there is no research on food wastage management either in the broader SANDF or in the South African Military Academy (SAMA) specifically. This is particularly alarming, considering concurrent international trends in the field of food wastage management within a military context - especially against the backdrop of growing concerns over food security. The authors therefore consider the literature applicable to food wastage management in general and food wastage management in a military context specifically, before discussing their research design, fieldwork and subsequent findings. Moss, Henrico and Smit conclude their article by recommending a number of measures to enhance food wastage management at the SAMA officer's mess in the future. 
The article by Marius Scheepers and Fransjohan Pretorius reports on the loss of military equipment by the South African Defence Force (SADF) at the Battle of Indungo in Angola on 31 October 1987 - specifically against the backdrop of Operation Firewood and the broader so-called Border War (1966-1989). By focusing on Operation Firewood, and the Battle of Indungo in particular, the article illustrates some of the circumstances under which the SADF lost military equipment in Angola during the war.

In the final article, William Wagner, Sonja van Putten and Willem Rauscher consider the existence of the professional military instructor identity (PMII) construct and its effect on the military ethos and quality of instruction to and by military instructors, based on the perceptions of a sample of military instructors in the SANDF. In the article, the authors point out the need for an institutionalised PMII in the SANDF, along with the promotion of professionalism and 'warriorism' where required. They argue that the institutionalisation of the PMII can be achieved among other through official doctrine, official support and perhaps even visual and monitory recognition by means of an instructor allowance. These measures, they argue, could help to improve both the military ethos and the training of and by military instructors, and in doing so, improve overall training in the SANDF.

A selection of book reviews by Jean-Pierre Scherman, Will Gordon, Emile Coetzee, Anri Delport, Ian van der Waag and Evert Kleynhans concludes this issue of Scientia Militaria.

\section{The Editor}

Evert Kleynhans 